\title{
疍 ČINIOCI UTICAJA NA DONOŠENJE ODLUKA O SPROVOĐENJU EVAKUACIJE U USLOVIMA KATASTROFA IZAZVANIH POŽARIMA U STAMBENIM OBJEKTIMA: STUDIJA SLUČAJA BEOGRADA*
}

\author{
Novak Mumović \\ Naučno-stručno društvo za upravljanje rizicima \\ u vanrednim situacijama, Beograd \\ Vladimir M. Cvetković \\ Univerzitet u Beogradu, Fakultet bezbednosti
}

\begin{abstract}
teoriji o katastrofama postoje nekonzistentni rezultati istraživanja u pogledu načina uticaja određenih činilaca na blagovremeno i adekvatno donošenje odluka o sprovođenju evakuacija u uslovima katastrofa izazvanih požarima u stambenim objektima. Predmet istraživanja predstavlja ispitivanje stavova građana u pogledu pristanka na evakuaciju, načinu i barijerama njenog sprovođenja, ali i uticaju internih (demografskih, socioekonomskih i psiholoških) činilaca na sprovođenje evakuacije u katastrofama izazvanim požarima na teritoriji Republike Srbije. Rezultati istraživanja pokazuju da bi se najveći broj građana evakuisao prilikom izbijanja požara u stambenim objektima. Pored toga, utvrđen je statistički značajan uticaj određenih demografskih i socio-ekonomskih činilaca na donošenje takvih odluka. U odnosu na građane koji bi odbili da se evakuišu, potrebno je sprovesti naknadna istraživanja kako bi se utvrdilo zašto oni odbijaju da se evakuišu i kojim se razlozima najviše rukovode.
\end{abstract}

Ključne reči: bezbednost, činioci, donošenje odluka, evakuacija, požari, stambeni objekti

Evakuacija se ubraja u najznačajnije mere zaštite stanovništva kojom se prema određenom planu, organizovano i masovno štiti stanovništvo, materijalna i kulturna dobra u uslovima vanrednih situacija (Cvetković \& Gačić, 2016). Predstavlja jednu od značajnijih mera civilne zaštite kojom se planski, organizovano i masovno štiti stanovništvo, njegova materijalna i kulturna dobra u uslovima vanrednih situacija. Sprovodi se u uslovima kada

\footnotetext{
* Rad je nastao kao rezultat istraživačkih aktivnosti autora u okviru pisanja master rada „Evakuacija iz stambenih objekata u vanrednim situacijama izazvanim požarima“ odbranjenog na Fakultetu bezbednosti, Univerziteta u Beogradu.
} 
drugim merama civilne zaštite nije moguće zaštititi ljude i materijalna dobra na određenom prostoru. Značajno je istaći da postoji suštinska razlika između evakuacije, pomeranja i premeštanja stanovništva (Jakovljević, 2011). Evakuacija zgrade predstavlja složen problem, jer u najvećem broju slučajeva evakuisana lica ne znaju ili ne prate optimalnu putanju evakuacije. Naročito u toku ispoljavanja opasnosti za prisutne u zgradi, pronalaženje najboljeg puta za evakuaciju postaje teže jer se uslovi na evakuacionoj stazi menjaju tokom samog postupka evakuacije (Filippoupolitis \& Gelenbe, 2009). Požar se može sprečiti ili se njime mora upravljati. U nekim slučajevima, pomeranje stanara kako bi se minimizirala njihova izloženost opasnosti je teško ili nepraktično. U ovim situacijama, poželjno je kontrolisanje ili uklanjanje opasnosti, posebno dok se opasnošću i dalje može upravljati. Zapravo, to je koncept koji podleže svim zahtevima za suzbijanje požara. Uspešna kontrola požara zavisi od toga da stanari prepoznaju pretnju od požara, odluče da odreaguju, biraju kako odgovore na opasnost, u slučaju izbora da suzbiju požar, da identifikuju, lociraju i koriste ispravan metod.

U periodu od 2007. do 2011. godine, vatrogasno-spasilačke jedinice u Sjedinjenim Američkim Državama odgovorile su u proseku na 15.400 požara u visokim zgradama. Ovi požari su izazvali sledeće posledice na godišnjem nivou: 46 civilnih smrtnih slučajeva; 530 civilnih povreda od požara; 219 miliona dolara imovinske štete. Tom prilikom, došlo se do vrlo interesantnih zapažanja da su četiri vrste imovine odgovorne za polovinu požara u visokim objektima: apartmani ( $45 \%$ svih požara u visokim objektima); hoteli ( $3 \%$ požara u visokim objektima); objekti za brigu o bolesnim licima (1\% požara u visokim objektima); kancelarije ( $2 \%$ požara u visokim objektima). Ostatak su uglavnom stambeni objekti koji se mogu naći u mešovitim stambenim ili poslovnim zgradama (u stambenim i poslovnim zgradama mešovite upotrebe) (kao što su restorani, prodavnice i parking garaže) ili mogućim pogrešno označenim objektima koji ne mogu biti visoki (kao što su stanovi i šupe) (Hall, 2000). Takođe, prema većini posmatranih parametara, rizici od požara i povezanih gubitaka niži su u visokim zgradama (visokogradnji) nego u drugim zgradama iste upotrebe. Glavni razlog zbog kojeg su rizici niži je verovatno mnogo veća upotreba sistema protivpožarne zaštite i alata u visokim zgradama u poređenju sa nižim građevinama (niskogradnjom). Takođe, kod visokih zgrada zabeležen je niži procenat požara sa oštećenjima od plamena izvan sobe porekla, pružajući dodatne dokaze o uticaju koji sistemi i alati protivpožarne zaštite imaju: stanovi ( $6 \%$ požara u visokim objektima naspram $10 \%$ u niskim zgradama); hoteli (6 \% požara u visokim objektima u poređenju sa $10 \%$ u nižim zgradama); objekti za brigu o bolesnim licima ( $5 \%$ požara u visokim objektima u odnosu na $8 \%$ u nižim zgradama); kancelarije ( $14 \%$ požara u visokim objektima u odnosu na $21 \%$ u nižim zgradama) (Hall, 2000).

Opšte je prihvaćeno zapažanje da se pojedinac u gomili obično ponaša drugačije nego kada je on/ona sam/a ili u maloj grupi (Braun, Musse, de Oliveira, \& Bodmann, 2003). lako razvoj vatre, od nastanka prvog plamena do punog požara, može trajati mnogo sati, vremenski period tokom kojeg su građani zgrade svesni požara i kao posledicu toga preduzimati neku akciju, obično je mnogo kraći, i može se meriti u minutima (Hareesh, 2000). Veliki je broj naučnika koji su došli do zaključka da je razumevanje ljudskog i društvenog ponašanja u vanrednim situacijama ključno za poboljšanje bezbednosti ljudi (grupe ljudi) na mestima javnih okupljanja (Cvetković et al., 2018; Cvetković et al., 2018; Cvetković, Roder, Öcal, Tarolli, \& Dragićević, 2018; Cvetković, Öcal, \& Ivanov, 2019; Fahy, 1995; Pan, Han, Dauber, \& Law, 2007; Ramachandran, 1990; Walker, Associates, \& Bryan, 1993). Protivpožarni propisi za zgrade i arhitektonski projekti (nacrtni, planovi), 
koji imaju za cilj da obezbede izlaz u slučaju opasnosti od požara, najčešće počivaju na neproverenim pretpostavkama. U spomenute pretpostavke često spada, da ljudi „paniče" u vatri i dimu i da ih je stoga najbolje držati u neznanju dok se opasnost ne utvrdi, da će pružanje više različitih izlaza u slučaju opasnosti koji će se koristiti samo u hitnim slučajevima sprečiti gomilu ljudi da pojure ka jednom izlazu, i borbu da pobegnu kroz isti. Ukratko, ovo se zove panični koncept ili scenario. Međutim, naučni dokazi o stvarnom ponašanju ljudi u požaru ne podržavaju ove koncepte, već nasuprot tome, pojedini naučnici ističu da se ljudi ponašaju racionalno u svetlu informacija koje imaju. Oni takođe pokazuju preferenciju prema poznatim rutama i izlazima, kao i brigu za sigurnost članova svojih porodice. Takav model se naziva model ,,pripadnosti” (Sime, 1984). Stambene, javne i poslovne zgrade, u kojima boravi ili se okuplja veći broj ljudi, naročito su izložene riziku od vanrednog događaja sa katastrofalnim posledicama, posebno riziku od vanrednog događaja izazvanog požarima (Laban, Popov, Vukoslavčević i Šupić, 2015).

U požarima često smrtno strada više osoba nego u svim drugim prirodnim katastrofama (Cvetković, 2019; Žarković, Kovačević, Kovač, \& Sarilar, 2014). Statistike pokazuju da je najveći procenat latentnih ishoda tokom požara nastaje usled udisanja otrovnog gasa prisutnog u dimu zbog neuspeha evakuacije iz zgrade (Gwynne, Galea, Owen, Lawrence \& Filippidis, 1999b). Podaci iz londonske vatrogasne brigade „Real Fire Library” jedinstvena baza podataka prikupljenih iz realnih požarnih incidenti od strane posvećenih timova vatrogasnih istražitelja koji rade u području „Greater London Area” korišćeni su za dobijanje čitavog niza statističkih podataka o smrtonosnim požarima i žrtvama požara za period od 5 godina, počevši od 1996. do 2000. godine. Većina smrtnih slučajeva dogodila se u nenamernim požarima koji su se dogodili u stanovima (stambeni objekti, kuće). Iz tog razloga se analiziraju statističke informacije kako bi se utvrdili glavni faktori koji su uključeni u to zašto ljudi umiru u nenamernim stambenim požarima i kako bi se videlo koje se pouke mogu izvući iz ovih kobnih događaja (Holborn, Nolan, \& Golt, 2003).

Društvo nastoji da odgovori na opasnost od požara u stambenim objektima na razne načine, uključujući intervenciju vatrogasnih službi, osiguranje, usvajanje i implementaciju propisa, edukacijom o opasnostima od požara, kontrolom upotrebe materijala i proizvode u zgradama, kao i dizajn zgrada odoleti efektima vatre (Xin \& Huang, 2013). Mnogi vanredni događaji uzrokovani požarima mogu se kontrolisati kada se njihovi uzroci identifikuju i shvate. Ponekad se vanredni događaji dešavaju čak i u sigurnim uslovima zbog lošeg plana, loše izgradnje, zloupotreba ili nedostatak održavanja. U slučaju požara ili drugih hitnih slučajeva u zgradama, moraju se doneti odredbe za sigurno i brzo izlazak putnika, posebno iz opasnih područja. Moraju se predvideti i sistemi za protivpožarnu zaštitu u bilo kojoj zgradi koja može pružiti zvučni i/ili vizuelni signal upozorenja ugroženim stanarima u slučaju požara. Dim je takođe veliki nusproizvod požara i neophodno je predvideti i usvojiti metode njegove kontrole još u fazi projektovanja (Al-Homoud \& Khan, 2004). Požari u stambenim zgradama su najznačajniji uzrok smrtnosti od požara u Sjedinjenim Državama (Runyan et al, 1992). Rezultati istraživanja sprovedenoj u ruralnim područjima u Severnoj Karolini u SAD su pokazali da su požari u stambenim objektima u najvećoj meri uzrokovani grejnim telima ili priborom za pušenje. Rizik za smrtni ishod je najveći kada je reč o požarima u mobilnim kućama, i kada je reč o onim osobama koje su pod dejstvom alkohola i kućama bez detektora dima. lako su vanredni događaji usled incidenata na grejnim telima bili glavni uzrok požara, požari izazvani pušenjem su u većoj meri uzrokovali smrtne ishode (31 procenat smrtonosnih požara naspram 6 procenata nefatalnih po- 
žara). Mobilne kuće su predstavljale veći rizik po smrtni ishoc ako je došlo do požara, kao i odsustvo detektora dima. Detektori dima su više štitili od smrti u požarima kada je reč o maloj deci i kada niko od prisutnih nije bio pod dejstvom alkohola ili droge, ili imao fizički ili mentalni invaliditet. Kada je osoba sa kognitivnim oštećenjem ili fizičkim invaliditetom bila prisutna, nedostatak detektora dima nije imao statistički značajnu vezu sa tim da li je vatra dovela do smrti. Prisustvo osobe koje su pod dejstvom alkohola predstavljao je najjači nezavisni faktor rizika za nastanak smrti u slučaju požara (Runyan et al, 1992). Upravo zato, upravljanje rizicima kao skup mera i aktivnosti za implementaciju različitih mera za smanjenje rizika od katastrofa predstavlja najznačajniji preduslov uspešnog ublažavanja posledica katastrofa (Aleksandrina, Budiarti, Yu, Pasha, \& Shaw, 2019; Kumiko \& Shaw, 2019; Ocal, 2019; Xuesong \& Kapucu, 2019).

\section{Pregled literature}

Efektivna evakuacija zgrade u slučaju vanrednih događaja kao što su požari, hemijska izlivanja ili širenje bioloških agenasa su odavno prepoznate kao važno pitanje, pre svega jer efikasno navođenje ljudi može poboljšati efikasnost izlaska, preživljavanje putnika i ublažavanje ili sprečavanje nepoželjnih posledice kao što su gomilanje ljudi ili blokiranje izlaza (Wang, Luh, Chang \& Sun, 2008). Među mnogim faktorima, uključujući i prenatrpanost i evakuacione incidente, istraživači su došli do zaključka da je razumevanje ljudskog i društvenog ponašanja u vanrednim situacijama ključno za poboljšanje bezbednosti ljudi na mestima javnih okupljanja (Fahy, 1995; Pan et al., 2007; Ramachandran, 1990; Walker et al., 1993).

Protivpožarne regulative za zgrade i arhitektonski projekti (nacrti, nacrtni planovi) koji imaju za cilj da obezbede izlaz u slučaju opasnosti od požara, počivaju na neistraženim pretpostavkama. U navedene pretpostavke spadaju, da ljudi ,,paniče" u vatri i dimu i da ih je stoga najbolje držati u neznanju dok se opasnost ne utvrdi, da će pružanje više različitih izlaza u slučaju opasnosti koji će se koristiti samo u hitnim slučajevima će sprečiti talas ka jednom izlazu, i borbu da pobegnu kroz isti. Ukratko, ovo se zove panični koncept ili scenario. Dokazi o stvarnom ponašanju ljudi u požaru to ne podržavaju (ne podržavaju ove koncepte). Kao što će biti pokazano, izgleda da se ljudi ponašaju racionalno u svetlu informacija koje imaju. Oni takođe pokazuju znatnu preferenciju prema poznatim rutama i izlazima, kao i brigu za sigurnost članova svojih porodice (Sime, 1984). U jednom od istraživanja (Hall, 2000), rezultati su pokazali da ponašanje stanara može biti pod uticajem fizičkih i psiholoških faktora, kao što su dim, situacija na putu evakuacije i panika. Čak i u istoj situaciji i uslovima, ljudi će se ponašati različito u smislu različitosti pola i starosne dobi. Faktori uticaja na ponašanje u uslovima požara se mogu podeliti na one koji postoje i pre događaja, one koji deluju tokom događaja i one koji zavise od broja i vrsta znakova i informacija tokom događaja. Kako se ovi faktori veoma razlikuju, kao i osobenosti pojedinaca, veoma je teško predvideti razvoj i tok procesa evakuacije zgrade u slučaju požara (Laban, Popov, Vukoslavčević i Šupić, 2015). Kada je reč o prirodi uticaja različitih faktora kao što su pol, godine, bračno stanje i prihodi domaćinstva na reagovanje u vanrednim događajima izazvanim požarima u naučnoj literaturi ne postoji saglasnost, iako se veliki broj autora bavi ispitivanjem istih (Bihari \& Ryan, 2012; Chien \& Wu, 2008; Cvetković, 2015; Cvetković \& Gačić, 2017; Holborn, Nolan, \& Golt, 2003; Kihila, 2017; McGee, McFarlane, \& Varghese, 2009; Nelson, Monroe, \& Johnson, 2005; Paton \& Tedim, 2012). 
U deskriptivnom istraživanju ponašanja ljudi pri simulaciji sistema za modelovanje kretanja velikog broja (mase) ljudi u zgradama pod dejstvom požara i ograničenih procedura evakuacije ustanovljeno je da ponašanje korisnika može biti pod uticajem fizičkih (kao što su dim, situacija na putu evakuacije), psiholoških faktora (panika), ali i demografskih (pol, godine starosti) (Li, Tang \& Simpson, 2004). Čak i u istoj situaciji i uslovima, ljudi će se ponašati drugačije u zavisnosti od pola i godina starosti. Na primer, jedno pitanje je posebno osmišljeno kako bi se saznalo na koji način ljudi biraju put evakuacije ako postoji razlika u reakciji kod osoba različitog pola i starosti. Rezultati istraživanja pokazuju da pol i starost imaju uticaja na odluke ljudi u smislu ignorisanja vatre, prikupljanje ličnih stvari, borbe protiv požara i izbora puta tokom procesa evakuacije požara. Primera radi, bila su postavljena sledeća pitanja: „Ako naiđete na sledeću situaciju za vreme evakuacije požara, koji put bi ste izabrati“. Ruta A sa dugom i jasnom stazom, put B je kraći, ali sa cik-cak stazom. U ovom slučaju rezultati istraživanja su pokazali da nije utvrđena značajna razlika kada je reč o različitim polovima ljudi i izbora evakuacione rute. Zapravo, većina ljudi bira jasnu rutu, iako je duža, dok jedva $20 \%$ ljudi bira cik-cak put. S druge strane, kada je reč o godinama starosti, ustanovljeno je da postoji značajna razlika između ljudi ispod i iznad 20 godina u izboru rute za evakuaciju. Oko 65\% ljudi koji su mlađi od 20 godina imaju tendenciju da biraju duži put, a samo 15\% njih bira kraću cik-cak rutu. U grupi ljudi preko 20 godina procenat ljudi koji biraju kraći put je pola u odnosu na broj ljudi koji biraju duži put. Nekoliko mladih ljudi, starosti ispod 20 godina, su intervjuisani kako bi se ustanovili razlozi zbog kojih oni biraju dužu rutu. Kao glavni razlog utvrđen je što oni misle da mogu da trče brže od drugih ljudi. Tako, njima ne smeta i ne brinu o dužini rute sve dok je reč o čistoj ruti. Takođe, došlo se do zaključka da pol ne utiče na izbor rute, ali starost je faktor, koji može da utiče na odluke ljudi usled vanrednih događaja (Li, Tang \& Simpson, 2004). Nakon odabira smera i rute za evakuaciju, u obzir treba uzeti i brzinu hodanja ka sledećem položaju. Opseg brzine hodanja zavisi od starosti, pola, profesije, zdravlja itd. (Shi, Ren \& Chen, 2009).

Prilikom donošenja odluka o sprovođenju evakuacije, ljudi često polaze od nekih svojih unutrašnjih motiva ali i od ambijentalnih faktora prilikom formiranja stava povodom toga. Na stavove ljudi o pristanku za sprovođenje evakuacije mogu uticati različiti faktori koji se osim demografskih, mogu razvrstati na socio-ekonomske i psihološke. Ne može se reći koji su značajni, ali se svakako mogu ispitati svi faktori kako bi se jasno utvrdilo koji su presudniji faktori. U velikom broju istraživanja ispitivani su uticaji socio-ekonomskih faktora i tom prilikom dolazilo se do različitih rezultata. Naime, u određenim istraživanjima je utvrđeno da je donošenje odluke o sprovođenju evakuacije pod direktnim uticajem visine prihoda dok druga istraživanja to ne potvrđuju (Lazo et al., 2015). Do sličnih rezultata se dolazi i kada je u pitanju uticaj straha ili percepcije rizika (Bryan, 1983).

U slučaju vanrednih događaja izazvanih požarima u stambenim objektima, stanari moraju da dođu do bezbednog mesta u zgradi. Ponašanje stanara tokom same evakuacije im omogućava da to urade na siguran ili manje siguran način. Preventivne mere sprečavanja nastanka i širenja požara u stambenim objektima u velikoj meri zavise od nivo svesti građana o takvim opasnostima. Ukoliko kod njih ne postoji svest o mogućnostima nastanka, vrstama i karakteristikama, načinima širenja i sprečavanja požara, teško će se opredeliti da obrate pojačanu pažnju i implementiraju određene strukturne (uređaji za dojavu i gašenje požara) i nestrukturne mere (edukacija članova domaćinstva) zaštite od požara (Cvetković \& Filipović, 2018). Pri tome, na osnovu percepcije verovatnoće na- 
stanka požara, može se indirektno zaključiti i o stepenu ugroženosti samog domaćinstva. Naime, ukoliko građanin smatra da je nivo verovatnoće izbijanja požara veći, može se pretpostaviti da on polazi od prethodnog iskustva, zapaženog stanja ugroženosti u svom domaćinstvu itd. (Cvetković \& Filipović, 2018). lako razvoj požara može trajati dugo, od prvog plamena do punog opsega požara, vremenski period tokom kojeg ljudi u zgradi postaju svesni požara i započnu preduzimanje određenih radnji, obično je mnogo kraći, što se može meriti u minutama. Unutar takvog okruženje, koje može uključivati neuobičajnu toplotu, dim i otrovne gasove, stanari će se ponašati na različite načine načine i haos može biti prouzrokovan osećajem uzbuđenja ili straha. Dakle, da bi se realno moglo simulirati grupno ponašanje ljudi, vrlo je važno istražiti i proučiti različita ponašanja usled takvih teškim uslovima (Li, Tang \& Simpson, 2004).

Razumevanje faktora koji utiču na odluku ljudi da se evakuišu ili ne je nezamislivo bez teorije planiranog ponašanja koja objašnjava različite motivacione varijable koje utiču na ponašanje ljudi, a pogotovo one na osnovu kojih se mogu dati određenje predikcije u vezi donošenja odluka o realizaciji evakuacije (Madden, Ellen, \& Ajzen, Ajzen, 1922). Naime, prema spomenutoj teoriji, stavovi kod ljudi se formiraju prema određenim uverenjima o samom ponašanju. Važan faktor u objašnjavanju namere ponašanja jeste subjektivna norma koja ukazuje da li je takvo ponašanje preporučljivo i opravdano (Conner \% Armitage, 1998). Spomenute namere su pod uticajem različitih faktora: stavovi prema određenom ponašanju, subjektivni kriterijumi, spoznajne kontrole ponašanja, kao i pretpostavka o međusobnoj interakciji (Icek Ajzen, 1991, 2002, 2011; Armitage \& Conner, 2001). Jedan od značajnih autora ističe (Ajzen, 1991, 1998; Madden et al., 1992) ističe da je sama teorija vrlo fleksibilna i ,,rastegljiva”. Ona je vrlo prilagodljiva za uključivanje drugih promenljiva ali pod uslovom da su sve promenljive korektno interpretiranje i da utiču na poboljšanje prediktivne sposobnosti. lako je predikciona moć teorije na visokom nivou, od strane određenih naučnika (Conner \& Armitage, 1998; Heath \& Gifford, 2002; Sparks, Chepherd, \& Frewer, 1995) je došlo do proširenja teorije planiranog ponašanja različitim promenljivama kao što su: prethodno iskustvo, različite navike, samoidentiteti, znanje o ponašanjima itd. Teorija se sastoji iz dva međusobno povezana elementa: percepcija mogućnosti kontrole nad ponašanjem i samouverenost u svoje sposobnosti (Cvetković, Filipović i Gačić, 2018).

Interesantno je spomenuti da se uslovi u zgradi mogu se promeniti usled prisustva opasnosti koja se širi (Gershon, 2006), kao što je požar ili opasan gas (Filippoupolitis \& Gelenbe, 2009). U prvom delu rada je spomenuto sa se može smatrati opšte prihvaćenom činjenicom da se pojedinac u gomili obično ponaša drugačije nego kada je sam ili u maloj grupi (Braun, Musse, de Oliveira, \& Bodmann, 2003). Kako razvoj vatre može trajati mnogo sati od nastanka prvog plamena do punog požara, vremenski period tokom kojeg su građani zgrade svesni požar i kao da za posledicu toga preduzmu neku akciju, obično je mnogo kraći, i može se meriti u minutima (Hareesh, 2000). U takvom okruženju, koje može uključivati neuobičajenu toplotu, dim i otrovna isparenja, stanari će se ponašati na različite načine, a haos može biti izazvati usled osećaja uzbuđenja ili straha. Stoga, kako bi se ponašanje grupe simuliralo na što realističniji način, vrlo je važno istražiti i proučavati spektar različitih ponašanja pod takvim teškim uslovima (Li, Tang \& Simpson, 2004). Iz ljudske kognitivno psihološke perspektive, ponašanje pojedinca može se posmatrati kao rezultat njegovog procesa donošenja odluka. Može se pretpostaviti da se proces odlučivanja pojedinaca sastoji od tri osnovna pravila: sledeći instinkt, sledeći 
iskustvo, i ograničenu racionalnost. Pojedinac može izabrati jedan ili kombinaciju više ovih osnovnih načina (običaja, ustaljenih pravila) kada se suočava sa vanrednom situacijom (nuždom, iznenadnim događajem), u zavisnosti od specifičnosti situacije sa kojom se pojedinac susreće (Pan et al., 2007). Predvideti na koji način će se ljudi ponašati u složenim i neizvesnim okruženjima kao što je evakuacija u vanrednim situacijama, smatra se skoro nemogućim u teoriji sistema (Joo et al., 2013). Međutim, u evakuaciji u realnom vremenu, ljudi se mogu ponašati prilično drugačije. Neki ljudi možda neće poštovati pravila u različitim i iznenadnim okolnostima (Bryan, 1983). U cilju realne simulacije ljudskog ponašanje u požaru u realnom vremenu, ove reakcije moraju biti predstavljene u simulacionom modelu (Li et al., 2004). Anketno istraživanje se sastojalo od 14 pitanja vezanih za postupak evakuacije u požaru, koji su dizajnirani tako da pokušaju da što realističnije prikažu ljudske reakcije na požarni događaj. Na primer, jedno pitanje je posebno osmišljeno u cilju saznanja na koji način (kako) ljudi biraju evakuacionu rutu i da li postoje razlike između starosti i pola u pogledu reakcije.

Rezultati istraživanja pokazuju da ne postoji značajna razlika između različitih polova u pogledu izbora evakuacione rute u ovoj situaciji. Većina ljudi će izabrati čistu putanju (rutu) uprkos tome što je duža. Skoro $20 \%$ ljudi odabire cik-cak rutu. lako se primećuju vidi da postoji značajna razlika između ljudi mlađih od 20 godina i onih starijih od 20 godina, kada je u pitanju izbor evakuacione rute. Oko $65 \%$ lica mlađih od 20 godina ima tendenciju da odabere duži put, a samo 15\% njih je sklono da odabere kraću cik-cak rutu. U grupi ljudi starijih od 20 godina, procenat ljudi koji biraju kraću rutu, iznosi polovina ljudi koji biraju duži put. Nekoliko mladih, mlađih od 20 godina intervjuisano je u cilju saznanja razloga zašto biraju dugu putanju. Glavni razlog je taj što misle odnosno smatraju da mogu da trče brže od drugih ljudi. Prema tome, njima ne smeta dužina rute sve dok je jasna (bezopasna, čista). Rezultati navedenog istraživanja pokazuju da rod nema uticaja na izbor rute, dok starost predstavlja faktor koji može uticati na odlučivanje ljudi u vanrednim situacijama. U simulacionom sistemu, kada se susretnu sa ovakvom situacijom, simulirani agenti su podeljeni u grupe prema starosnoj dobi, kako bi realno predstavili različita ljudska ponašanja u realnom vremenu (Li et al., 2004). Sa druge strane, rezultat pokazuje da pol i godine imaju uticaja na odluku stanara u smislu ignorisanja požara, prikupljanja ličnih stvari, borbe sa vatrom i selekcije rute tokom procesa protivpožarne evakuacije (Li et al., 2004). Podaci o vremenu odlaganja koji se odnose na poslovne zgrade, srednje i visoke zgrade i prodavnice objavljeni su u nekoliko radova (Rita F Fahy \& Proulx, 2001; Guylene Proulx, 1995; Guléne Proulx, Latour, \& MacLaurin, 1994; Shields \& Boyce, 2000). Studije su pokazale da će se vreme odlaganja stanara razlikovati u skladu sa signalom koji su primili (na primer, alarm, upozorenja od osoblja, glasovne poruke ili dim). Još jedan element u preživljavanju požara u visokoj zgradi jeste sposobnost stanara da efikasno pobegnu. Studija u vidu ankete koju je 2007. godine obavila kompanija ,NuStats za Fire Protection Research Foundation“ otkrila je da su nivoi znanja i spremnosti u koji su vezani za spremnost za beg, bili sasvim različiti za stanovnike visokih komercijalnih zgrada (po svoj prilici kancelarije) u poređenju sa stanarima visokih stambenih objekta (po svoj prilici stanovi). Posebno se ističe da su protivpožarne vežbe mnogo češće među stanarima visokih poslovnih zgrada ( $83 \%$ je učestvovalo u vežbi u toku protekle godine) nego u stambenim zgradama (19\%). Takođe, baterijske lampe su mnogo češće u posedu stanara visokih stambenih zgrada $(76 \%)$ nego u posedu stanara komercijalnih zgrada $(30 \%)$. 
Kada požar u visokoj zgradi fatalno povredi ljude koji nisu bili na spratu na kom je vatra nastala, obično se dogodi neka vrsta nepravilnosti ili kvara u održavanju zaštite stepeništa ili liftova. Evo nekoliko primera: lift putuje do sprata na kome ima požara i otvara se. Ovaj problem je u velikoj meri eliminisan redizajniranjem liftova i istaknutim prikazom upozorenja protiv korišćenja lifta tokom požara. Stariji primer požara u kojem je pet ljudi poginulo u ovakvim uslovima dokumentovano je u ,Laurence D. Watrous, Fatal hotel fire: New Orleans", Fire Journal, January 1972, str. 5-8"; vrata do izlaznih stepenica otvorena su i blokirana i omogućavaju ulazak dima ili vatre. Primer sa višestrukim smrtnim slučajevima dokumentovao je ,,Mike Isner u, "Smoking fire kills four in New York high-rise," Fire Journal, September/October 1988, pp. 72-77". Nestandardno ili drugo neadekvatno ili neusaglašeno ograđivanje stepenica omogućava da dim izađe na stepenište (Hall, 2000). U bliskoj budućnosti se može očekivati da će zgrade biti opremljene nizom bežičnih senzora i aktivatora koji će funkcionisati kao deo celokupnog sistema za upravljanje zgradom. U ovaj set senzora biće uključeni uređaji za praćenje požara i dima i reagovanje na primljene signale, omogućavajući otkrivanje, lokalizaciju i praćenje požara, i pružanje smernica evakuisanim licima i vatrogasno-spasilačkim jedinicima o napretku vatre, putevima za bekstvo i lokacijama na kojima se nalaze ljudi kojima je potrebna pomoć (Zeng et al., 2009).

\section{Metodološki okvir istraživanja}

Uvidom u veći broj naučnih radova iz oblasti evakuacije građana iz stambenih objekata utvrđeno je da su rezultati sprovedenih istraživanja vrlo nekonzistentni i da postoji manji broj istraživanja u Srbiji iz spomenute oblasti (videti opširnije Cvetković i Gačić, 2016). Iz tih razloga, potrebno je dati odgovore na sledeća istraživačka pitanja:

- Prvo istraživačko pitanje - U kojoj meri građani pristaju da se evakuišu iz stambenih objekata u slučajevima kada je požar izbio na neposredno višim ili nižim spratovima zgrade. Koje karakteristike građana utiču na njihovu odluku da pristanu ili odbiju da se evakuišu u takvim situacijama;

- Drugo istraživačko pitanje - Da li su karakteristike građana kao što su pol, godine, bračno stanje i prihodi domaćinstva prediktor pristanka i načina donošenja odluke od strane građana da se evakuišu u slučajevima vanrednih situacija izazvanih požarima u stambenim objektima.

- Treće istraživačko pitanje - Sa druge strane, da li stavovi građana o samoj evakuaciji, kao i motivacija, percepcija rizika, strah i znanje predstavljaju prediktor pristanka i načina donošenja odluke od strane građana da se evakuišu u slučajevima vanrednih situacija izazvanih požarima u stambenim objektima.

Proces donošenja odluka o pristanku na evakuaciju od trenutka saznanja za nastanak vanredne situacije izazvane požarom uslovljen je velikim brojem eksternih i internih faktora. Pod eksternim faktorima podrazumevaju se pre svega izgrađene strukture, razvijene procedure i tehnološke inovacije koje omogućavaju i olakšavaju sprovođenje brze i bezbedne evakuacije. Sa druge strane, iako postoje objekti izgrađeni u skladu sa važećim standardima u odnosu na sprovođenje evakuacije, njena uspešnost u velikoj meri zavisi i od samih ljudi. Upravo interni faktori pod kojima se podrazumevaju demografske, socio-ekonomske i 
psihološke karakteristike ispitanika. Predmet istraživanja se odnosi na ispitivanje stavova građana o pristanku na evakuaciju, načinu i barijerama njenog sprovođenja, ali i uticaju internih (demografskih, socio-ekonomskih i psiholoških faktora) na sprovođenje evakuacije u vanrednim situacijama izazvanim požarima u Srbiji. Konkretnije rečeno, ispitani su stavovi građana o tome da li bi pristali da se evakuišu i pod kojim uslovima; zašto se ne bi evakuisali i na koji način se mogu premostiti spomenute barijere; na koji način pol, godine starosti, bračni status, prihodi građana, stavovi i motivisanost utiču na proces donošenja odluke o sprovođenju evakuacije. Ispitivanjem nivo spremnosti za sprovođenje evakuacije ako i prirode uticaja spomenutih faktora ostvaruju se preduslovi za osmišljavanje i implementaciju različitih programa, strategija i kampanja koje će unaprediti stanje u spomenutoj oblasti. Operacionalizacijom teorijskog određena evakuacija izveden je skup dimenzija koji je ispitivan: pristanak na evakuaciju; znanje o evakuaciji; poznavanje puteva evakuacija; skloništa; posedovanje neophodne opreme itd.

Polazeći od dinamične prirode procesa donošenja odluke i samog sprovođenja evakuacije istraživanje se bazira na 2019. godinu kada sprovedena realizacija terenskog istraživanja. Istraživanjem su obuhvaćena iskustva građana i sa ranijim vanrednim događajima u kojima su se susreli sa zahtevima za evakuacijom. Teritorija grada Beograda je veoma ugrožena požarima pogotovo imajući u vidu veliki broj stambenih objekata na njenoj teritoriji. U skladu sa zvaničnim podacima dobijenim od Sektora za vanredne situacija, u Srbiji je u poslednje dve godine bilo 79.886 požara i eksplozija u kojima je poginulo ili povređeno 1.280 ljudi, a najviše njih bilo je na otvorenom prostoru. Polazeći od jasno definisanog predmeta istraživanja, za realizaciju kvantitativnog istraživanja odabran je grad Beograd u kojem će se sprovesti anketiranje građana. Priroda načina donošenja odluka o procesu sprovođenja evakuacije zahteva multidisciplinarni pristup. U radu su korišćeni pristupi društvenih i prirodnih naučnih disciplina kako bi se sveobuhvatno razumela tretirana problematika. Teorijski deo istraživanja bazira se na metodi analize sadržaja, istorijskoj i komparativnoj metodi. Metoda analize sadržaja korišćena je za proučavanje strane i domaće naučne literature, stranih i domaćih naučnih časopisa u kojima se razrađuje problematika donošenja odluka o sprovođenju evakuacije. Pored toga, analizirana je strana i domaća normativno-pravna akta o svim aspektima sprovođenja evakuacije.

Proces sprovođenja evakuacije je vrlo složen i u velikoj meri uslovljen različitim faktorima. Pored samih standarda gradnje, nivoa tehničke opremljenosti objekata i razvijenih procedura, uspešnost njene realizacije u velikoj meri zavisi od čitavog spleta različitih psiholoških karakteristika građana. Polazeći od pregleda literature u kojem su prikazani nekonzistentni rezultati različitih segmenta sprovođenja evakuacije, postoji velika razlika između muškaraca i žena, starijih i mlađih građana, sa višim i nižim prihodima u procesu donošenja odluka o pristanku i načinu sprovođenja evakuacije. Polazeći od prethodno elaboriranog predmeta istraživanja, cilj istraživanja predstavlja naučna deskripcija i objašnjenje načina donošenja odluka o pristanku i načinu sprovođenja evakuacije u vanrednim situacijama izazvanim požarima u stambenim objektima. lako se mogu preduzeti sve preventivne mere da do požara ne dođe, one se često ne preduzimaju te su građani suočeni sa neophodnošću sprovođenja evakuacije. Ono što je moguće preduzeti jeste da se unapredi svest građana, da se edukuju i pripreme za preduzimanje preventivnih mera od kojih je značajna pravovremena i adekvatna evakuacija. Upravo zato, potrebno je detaljno ispitati na koji način građani donose odluke o 
sprovođenju evakuacije, koje su to barijere i na koji način utiču različiti faktori. Davanje odgovora na pitanje da li bi se građani evakuisali u vanrednim situacijama izazvanim požarima i koji faktori utiču na donošenje takvih odluka predstavlja važan preduslov za nadležne države organe koji mogu na bazi takvih saznanja doneti odgovarajuće strategije i programe za unapređenje svesti stanovnika.

Rezultati istraživanja doprinose unapređenju teorijskog i empirijskog fonda naučnih saznanja i omogućavaju komparaciju sa rezultatima prethodnih istraživanja (Carpenter, 2003; Gwynne, Galea, Owen, Lawrence, \& Filippidis, 1999a; Moritz, 2003). Takođe, omogućena je i sistematizacija postojećeg znanja o različitim aspektima sprovođenja evakuacije iz stambenih objekata. Multidisciplinarnost projektovanog istraživanja uslovila je korišćenje različitih izvora podataka: postojeći izvori podataka i podaci koji će biti generisani realizacijom terenskih istraživanja. Što se tiče postojećih izvora podataka, u istraživanju su korišćeni svi izvori normativno-pravne regulative u zemlji i inostranstvu. Takođe, korišćeni su izveštaji Sektora za vanredne situacije, relevantne publikacije međunarodnih organizacija, knjige i naučni časopis. U realizaciji svih spomenutih izvora koristile su se sledeće metode: sekundarna analiza, analiza sadržaja, uporedna pravna analiza i pregled literature. Kada je reč o podacima koji će biti generisani korišćeno je anketiranje građana sa ciljem ispitivanja njihovih stavova.

U sprovođenju istraživanja o uticaju demografskih, socio-ekonomskih i psiholoških karakteristika građana na proces donošenja odluka o pristanku i načinu sprovođenja evakuacije korišćen je kvantitativni istraživački pristup. Da bi se ispitali stavovi građana o načinu donošenja odluka prilikom sprovođenja evakuacije prikupljeni su osnovni podaci o karakteristikama samih ispitanika i njihovim stavovima o načinu donošenja odluka o sprovođenju evakuacije iz stambenih objekata. Po završetku anketiranja, svi anketni upitnici dobili su jedinstvene identifikacione oznake pod kojima su zavedeni u bazu podataka za njihovu obradu SPSS. Pre nego što se pristupilo analizi podataka, svi podaci su prošli određene preliminarne analize kako bi se ispravile eventualne greške načinjene prilikom unosa podataka. Po završetku pripreme podataka, pristupilo se deskriptivnim i inferencijalnim statističkim analizama.

Pre nego što se pristupilo anketiranju, analizom domaćih i stranih naučnih publikacija identifikovana su sva istraživanja u kojima su korišćeni anketni upitnici sa ciljem adaptacije i kreiranja anketnog upitnika za realizaciju istraživanja. Nakon toga, kreiran je anketni upitnik čija je unutrašnja saglasnost bila ispitana u programu za statističku obradu podataka. Takođe, sprovedeno je i pilot istraživanje sa ciljem provere da li su uputstva, pitanja i vrednosti na skalama jasni. Pored toga, posebna pažnja bila je posvećena utvrđivanju da li ispitanici razumeju sve stavke ankete. Populaciju čine svi punoletni stanovnici lokaInih zajednica u Beogradu koji žive u stambenim objektima. Metodom slučajnog uzorka odabrane su zgrade u kojima je sprovedeno anketiranje. Nakon toga, slučajnim odabirom su selektovana i domaćinstva u kojima je sprovedeno anketiranje. Na kraju, svaki muški i ženski punoletni građanin (princip sledećeg rođendana) koji se našao u stanu je anketiran. Anketirano je ukupno 189 građana od čega $55.33 \%$ ispitanika ženskog i $44.67 \%$ ispitanika muškog pola. $U$ odnosu na godine starosti ispitanika, najviše je ispitanika $42.30 \%$ od 18 do 30 godina života. Kada je u pitanju nivo obrazovanja, rezultati pokazuju da je najviše ispitanika sa završenom srednjom školom $76.72 \%$. Najviše je ispitanika sa završenom srednjom školom $45.50 \%$ (tabela 1). 
Tabela 1 - Struktura uzorka ( $n=189)$.

\begin{tabular}{llrr}
\hline Varijabla & Kategorija & $\mathrm{N}$ & $\%$ \\
\hline \multirow{2}{*}{ Pol } & Muški & 88 & 44.67 \\
& Ženski & 109 & 55.33 \\
\hline \multirow{3}{*}{ Godine } & $18-30$ & 80 & 42.30 \\
& $31-50$ & 79 & 41.80 \\
& Preko 51 & 30 & 15.90 \\
\hline \multirow{3}{*}{ Nivo obrazovanja } & Osnovno & 5 & 2.65 \\
& Srednje & 145 & 76.72 \\
& Više & 20 & 10.58 \\
& Fakultet & 19 & 10.05 \\
\hline \multirow{3}{*}{ Bračni status } & Nije u vezi & 60 & 31.75 \\
& U vezi & 86 & 45.50 \\
& U braku & 38 & 20.11 \\
& Razveden & 5 & 2.65 \\
\hline
\end{tabular}

Po završetku anketiranja, anketni upitnici su složeni po identifikacionim oznakama i započet je unos u bazu podataka koja omogućava statističku obradu podataka. Nakon toga, sprovedene su preliminarne analize podataka sa ciljem identifikovanja određenih grešaka prilikom unosa. Pronađeni nedostaci su otklonjeni tako što se se izvršio naknadni unos u bazu u odnosu na šifru anketnog upitnika. Analiza podataka zasnivala se na deskriptivnim statističkim analizama, konkretnije na utvrđivanju frekvencija, izračunavanju procenata i srednjih vrednosti. Navedena primena deskriptivne statistike podrazumevala je: mere centralne tendencije (srednja vrednost, medijana i modus); mere disperzije (interval varijacije, standardna devijacija i koeficijent varijacije); i mere oblika rasporeda (simetričnost i spljoštenost). Pri tome, za dobijanje opisnih statističkih pokazatelja kategorijskih promenljiva, upotrebljena je učestalost (Frequencies) njihovih vrednosti, dok će se za neprekidne promenljive upotrebiti funkcija (Descritpives). Od tehnika, korišćene su odgovarajuće odnosno prikladne tehnike za istraživanje veza između promenljivih (npr. starosti i stavova o evakuacije) i tehnike za istraživanje razlika između grupa (npr. polnih razlika u stavovima).

\section{Rezultati istraživanja}

Požari nastali u stambenim objektima prouzrokuju ozbiljne probleme kada je u pitanju sprovođenje evakuacije. U određenim slučajevima, preporučljivije je da se ostane u stanu ukoliko požar direktno ne ugrožava bezbednost ljudi i njihove imovine. Naime, ukoliko je požar izbio na prvom spratu zgrade, produkti sagorevanja tj. dim ispuniće stepenišni prostor zgrade i na taj način smanjiti vidljivost koja može ozbiljno da ometa ljude prilikom evakuacije. Upravo zato, preporučljivo je da se sačeka dolazak nadležnih vatrogasnospasilačkih jedinica nego da se započne evakuacija. Iz tih razloga, ispitanicima je postavljeno pitanje u pogledu njihovih stavova o tome. Na postavljeno pitanje: „,Da li biste se evakuisali u slučajevima požara u stambenim objektima" $85.7 \%$ građana je odgovorilo da bi se evakuisali, dok je 15.3\% odgovorilo da se ne bi evakuisali (grafikon 1). 


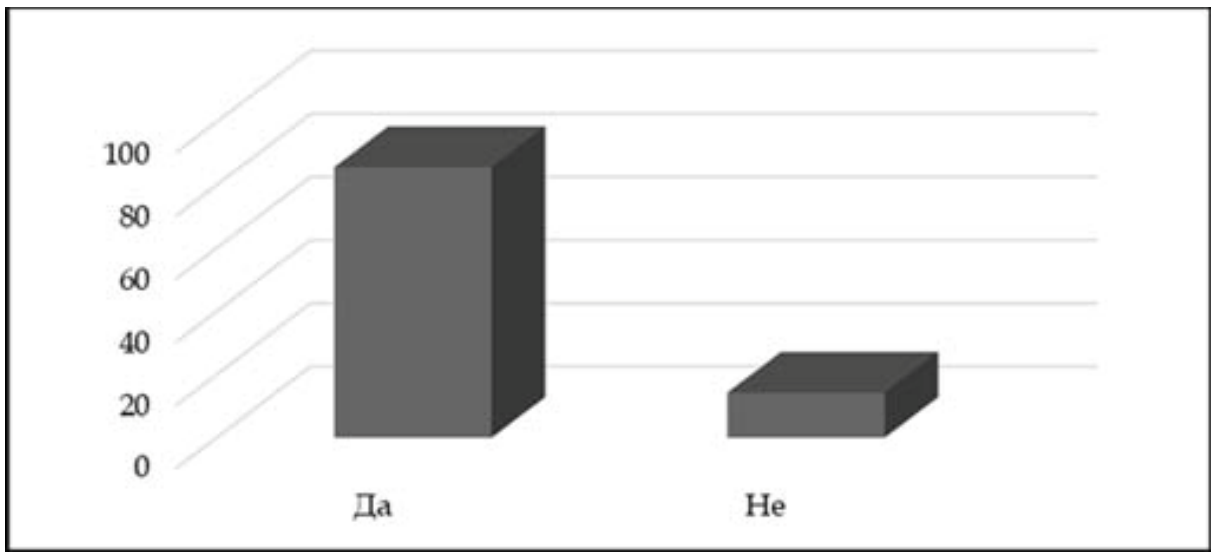

Grafikon 1 - Procentualna distribucija stavova u pogledu pristanka na evakuaciju. Izvor: obrada autora.

Polazeći od istraživačkog pitanja da li postoji uticaj demografskih karakteristika građana na stavove građana o pristanku na evakuaciju ispitan je uticaj pola, godina starosti i bračnog statusa. $U$ odnosu na istraživačko pitanje, ispitan je uticaj pola na donošenje odluke o pristanku na evakuaciju. Posebna pažnja je usmerena na pitanje da li postoji razlika između muškaraca i žene prilikom donošenja odluke da se evakuišu prilikom požara u stambenim objektima. Analize pokazuju da bi se evakuisalo $79.3 \%$ žena i $88.2 \%$ muškaraca, dok se ne bi evakuisalo ukupno $14.6 \%$ ispitanika (tabela 2 ).

Tabela 1 - Rezultati unakrsnog tabeliranja pola i sprovođenja evakuacije

\begin{tabular}{|c|c|c|c|c|c|}
\hline & & & \multicolumn{2}{|c|}{ Pristanak na evakuaciju } & \multirow{2}{*}{ Ukupno } \\
\hline & & & $\mathrm{Da}$ & $\mathrm{Ne}$ & \\
\hline \multirow{4}{*}{ Pol ispitanika } & \multirow{2}{*}{ Muški } & $\mathrm{N}$ & 46 & 12 & 58 \\
\hline & & $\%$ & 79.3 & 20.7 & 100.0 \\
\hline & \multirow{2}{*}{ Ženski } & $\mathrm{N}$ & 112 & 15 & 127 \\
\hline & & $\%$ & 88.2 & 11.8 & 100.0 \\
\hline \multirow[b]{2}{*}{ Ukupno } & & $\mathrm{N}$ & 158 & 27 & 185 \\
\hline & & $\%$ & 85.4 & 14.6 & 100.0 \\
\hline
\end{tabular}

Nakon unakrsnog tabeliranja, pristupilo se ispitivanju statističke povezanosti pola i sprovođenja evakuacije. Rezultati hi kvadrat testa pokazuju da ne postoji povezanost između pola i donošenja odluka o evakuaciji $(p=.113)$. Pored pola, ispitan je i uticaj godina starosti na pristanak sprovođenja evakuacije. Tom prilikom, najpre su analizirani rezultati unakrsnog tabeliranja. Ispitanici su bili razvrstani u tri kategorije: do 30 godina, do 50 godina i preko 51 godinu. Od ukupnog broja ispitanika starosti do 30 godina, $77.5 \%$ bi pristalo da se evakuiše, dok $22.5 \%$ to ne bi učinilo. U odnosu na ispitanike do 50 godina, $88.3 \%$ bi pristalo da se evakuiše, dok to ne bi učinilo $11.7 \%$. U kategoriji ispitanika preko 51 godine, svi ispitanici bi pristali da se evakuišu (tabela 3 ). 
Tabela 3 - Rezultati unakrsnog tabeliranja godina starosti i sprovođenja evakuacije

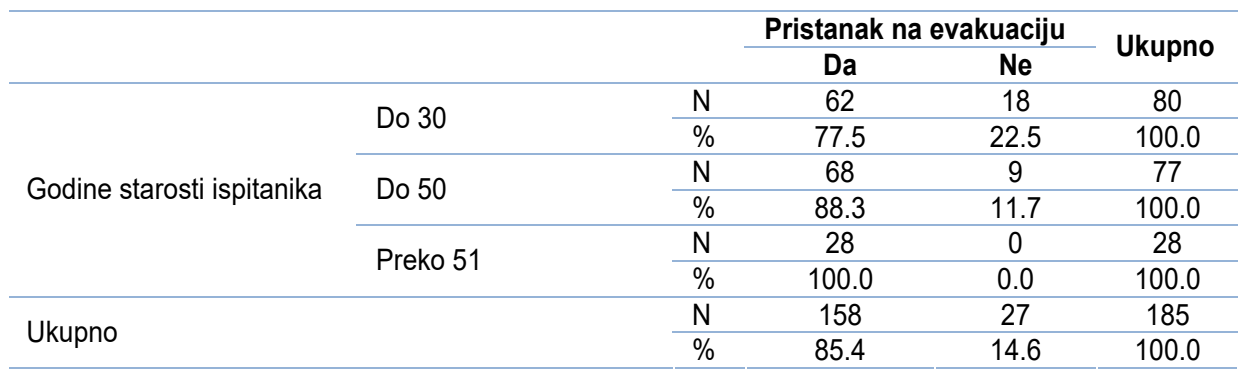

Po završetku analize rezultata unakrsnog tabeliranja, pristupilo se ispitivanju statistički značajne povezanosti godina starosti i sprovođenja evakuacije. Dobijeni rezultati istraživanja pokazuju da postoji statistički značajna povezanost godina ispitanika i sprovođenja evakuacije $(p=.009)$. Analiza rezultata pokazuje da su najstariji ispitanici u najvećoj meri spremni da se evakuišu u slučajevima požara u stambenim objektima. Nakon ispitivanja povezanosti pola i donošenja odluka o sprovođenju evakuaciju, pristupili smo ispitivanju uticaja bračnog statusa na pristanak za sprovođenje evakuacije. Ispitanici su prema bračnom statusu bili razvrstani u sledeće kategorije: nije u vezi, u vezi, veren/a, oženjen/udata, udovac/ica. Rezultati unakrsnog tabeliranja pokazuju da od ukupno 93 ispitanika koji nisu u vezi, $89.2 \%$ bi se evakuisalo, dok $10.8 \%$ to ne bi učinilo. U odnosu na ispitanike koji su u vezi, $81.9 \%$ bi se evakuisalo, dok $18.1 \%$ to ne bi učinilo. Kada je reč o ispitanicima koji su vereni, samo jedan ispitanik koji je pripadao toj kategoriji dao je potvrdan odgovor. U odnosu na oženjene/udate ispitanike, $71.4 \%$ bi se evakuisalo dok $28.6 \%$ to ne bi učinilo. I na kraju, od jednog ispitanika koji je udovac/ica dobijen je pozitivan odgovor u vezi sprovođenja evakuacije (tabela 4).

Tabela 4 - Rezultati unakrsnog tabeliranja bračnog statusa i sprovođenja evakuacije

\begin{tabular}{|c|c|c|c|c|c|}
\hline & & & nak na & & Ukupno \\
\hline & & & $\mathrm{Da}$ & $\mathrm{Ne}$ & \\
\hline & & $\mathrm{N}$ & 83 & 10 & 93 \\
\hline & NIJe u vezI & $\%$ & 89.2 & 10.8 & 100.0 \\
\hline & & $\mathrm{N}$ & 68 & 15 & 83 \\
\hline & U vezi & $\%$ & 81.9 & 18.1 & 100.0 \\
\hline$\frac{\pi}{\omega}$ & & $\mathrm{N}$ & 1 & 0 & 1 \\
\hline , & Veren/a & $\%$ & 100.0 & 0.0 & 100.0 \\
\hline & Ǒ̌nnionludato & $\mathrm{N}$ & 5 & 2 & 7 \\
\hline & Uzenjen/udata & $\%$ & 71.4 & 28.6 & 100.0 \\
\hline & & $\mathrm{N}$ & 1 & 0 & 1 \\
\hline & Udovac/ıca & $\%$ & 100.0 & 0.0 & 100.0 \\
\hline & & $\mathrm{N}$ & 158 & 27 & 185 \\
\hline & & $\%$ & 85.4 & 14.6 & 100.0 \\
\hline
\end{tabular}

Po završetku analiza rezultata unakrsnog tabeliranja, pristupilo se ispitivanju statistički značajne povezanosti bračnog statusa i sprovođenja evakuacije. Dobijeni rezultati su pokazali da ne postoji statistički značajna povezanost posmatranih promenljiva $(p=.502)$. U da- 
ljem radu, pristupilo se ispitivanju povezanosti nivoa obrazovanja i sprovođenja evakuacije. Rezultati unakrsnog tabeliranja pokazuju da od ukupnog broja ispitanika koji su završili osnovnu školu, njih $88.2 \%$ bi se evakuisalo, dok $11.8 \%$ to ne bi učinilo. Ispitanici koji su završili srednju školu su podeljeni u dve grupe: oni koji su završili četvorogodišnje i trogodišnje škole. Od ukupnog broja ispitanika koji su završili četvorogodišnje škole, njih $87.1 \%$ bi pristalo da se evakuiše, dok $12.9 \%$ to ne bi učinilo. Sa druge strane, od ukupnog broja ispitanika koji su završili trogodišnje škole njih $80 \%$ bi se evakuisalo dok $20 \%$ to ne bi učinilo. Među ispitanicima koji su završili višu školu, samo jedan ispitanik je odgovorio da bi se evakuisao. Na kraju, u odnosu na visoko obrazovanje $42.9 \%$ bi pristalo da se evakuiše dok $57.1 \%$ to ne bi učinilo (tabela 4).

Tabela 4 - Rezultati unakrsnog tabeliranja nivoa obrazovanja i sprovođenja evakuacije

\begin{tabular}{|c|c|c|c|c|c|}
\hline & & & Pristana & uaciju & llkunno \\
\hline & & & $\mathrm{Da}$ & $\mathrm{Ne}$ & 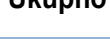 \\
\hline & Osnovpn & $\mathrm{N}$ & 15 & 2 & 17 \\
\hline & 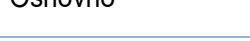 & $\%$ & 88.2 & 11.8 & 100.0 \\
\hline & Srodnis ( 3 andina) & $\mathrm{N}$ & 4 & 1 & 5 \\
\hline & sreanje (3 goaına) & $\%$ & 80.0 & 20.0 & 100.0 \\
\hline Nivn ohrazovania & Srednie (4 andina) & $\mathrm{N}$ & 135 & 20 & 155 \\
\hline TVIVo odrazovanja & sreanje (4 goaina) & $\%$ & 87.1 & 12.9 & 100.0 \\
\hline & & $\mathrm{N}$ & 1 & 0 & 1 \\
\hline & Vise oprazovanje & $\%$ & 100.0 & 0.0 & 100.0 \\
\hline & Visoko obrazoyanie & $\mathrm{N}$ & 3 & 4 & 7 \\
\hline & visoko oprazovanje & $\%$ & 42.9 & 57.1 & 100.0 \\
\hline Ukunno & & $\mathrm{N}$ & 158 & 27 & 185 \\
\hline Ukuprio & & $\%$ & 85.4 & 14.6 & 100.0 \\
\hline
\end{tabular}

U daljem radu, ispitan je uticaj nivoa obrazovanja ispitanika i sprovođenja evakuacije. Dobijeni rezultati istraživanja su pokazali da postoji statistički značajna povezanost između nivoa obrazovanja i sprovođenja evakuacije $(p=.027)$. Analizom dobijenih rezultata, utvrđeno je da ispitanici koji imaju visoko obrazovanje u najmanjoj meri pristaju da se evakuišu u slučajevima izbijanja požara u stambenim objektima. Polazeći od istraživačkog pitanja da li postoji uticaj socio-ekonomskih karakteristika građana na stavove građana o pristanku na evakuaciju ispitan je uticaj visine prihoda, percepcije rizika, straha i prethodnog iskustva. Na sprovođenje evakuacije odnosno donošenje odluke o pristanku na evakuaciju deluje veliki broj faktora, kao što je visina prihoda ali i percepcija rizika. Rukovodeći se postavljenim istraživačkim pitanjima, najpre je ispitana povezanost visine prihoda i donošenja odluke o sprovođenju evakuacije. Dobijeni rezultati unakrsnog tabeliranja pokazuju da od ukupno 34 ispitanika koji imaju prihode do 25.00 dinara $88.2 \%$ bi pristalo da se evakuiše dok $11.8 \%$ to ne bi pristalo. Sa druge strane, od ukupnog broja ispitanika koji imaju prihode od 26.000 do 50.000 dinara $81.7 \%$ bi pristalo da se evakuiše dok $18.3 \%$ to ne bi pristalo. Na kraju, od ukupnog broja ispitanika koji imaju prihode preko 76.000 dinara $69.6 \%$ bi pristalo da se evakuiše dok $30.4 \%$ ne bi pristalo (tabela 5 ). 
Tabela 5 - Rezultati unakrsnog tabeliranja visine prihoda i sprovođenja evakuacije

\begin{tabular}{|c|c|c|c|c|c|}
\hline & & & stanak & aciju & \\
\hline & & & $\mathrm{Da}$ & $\mathrm{Ne}$ & Ukupno \\
\hline & 25000 din & $\mathrm{N}$ & 30 & 4 & 34 \\
\hline & Do 25.000 din & $\%$ & 88.2 & 11.8 & 100.0 \\
\hline & Od 26000 do 50000 din & $\mathrm{N}$ & 49 & 11 & 60 \\
\hline Nivo prihoda & $00, \angle 6.000$ do $50.000 \mathrm{din}$ & $\%$ & 81.7 & 18.3 & 100.0 \\
\hline & Od 51000 do 75000 din & $\mathrm{N}$ & 30 & 1 & 31 \\
\hline & & $\%$ & 96.8 & 3.2 & 100.0 \\
\hline & Preko 76.000 din & $\mathrm{N}$ & 16 & 7 & 23 \\
\hline & & $\%$ & 69.6 & 30.4 & 100.0 \\
\hline Ukupno & & $\mathrm{N}$ & 125 & 23 & 148 \\
\hline & & $\%$ & 84.5 & 15.5 & 100.0 \\
\hline
\end{tabular}

Nakon završenog unakrsnog tabeliranja, pristupilo se ispitivanju statistički značajne povezanosti visine prihoda i sprovođenja evakuacije. Tom prilikom utvrđeno je da postoji statistički značajna povezanost $(p=.042)$. Dobijeni rezultati ispitivanja pokazuju da bi se u najmanjoj meri evakuisali ljudi koji imaju primanja preko 76.000 dinara. Po završetku ispitivanja povezanosti visine prihoda i sprovođenja evakuacije, pristupilo se ispitivanju povezanosti percepcije rizika i evakuacije. Rezultati unakrsnog tabeliranja ukazuju da od ukupnog broja ispitanika koji percipiraju rizik njih $93.8 \%$ bi se evakuisalo, dok $6.2 \%$ se ne bi evakuisalo. Od ukupnog broja ispitanika koji nisu sigurni, $71.2 \%$ bi se evakuisalo, dok $28.8 \%$ to ne bi uradilo. I na kraju, od ukupnog broja ispitanika koji ne percipiraju rizika $87.3 \%$ bi se evakuisalo, dok $12.7 \%$ to ne bi učinilo (tabela 6 ).

Tabela 6 - Rezultati unakrsnog tabeliranja percepcije rizika i sprovođenja evakuacije

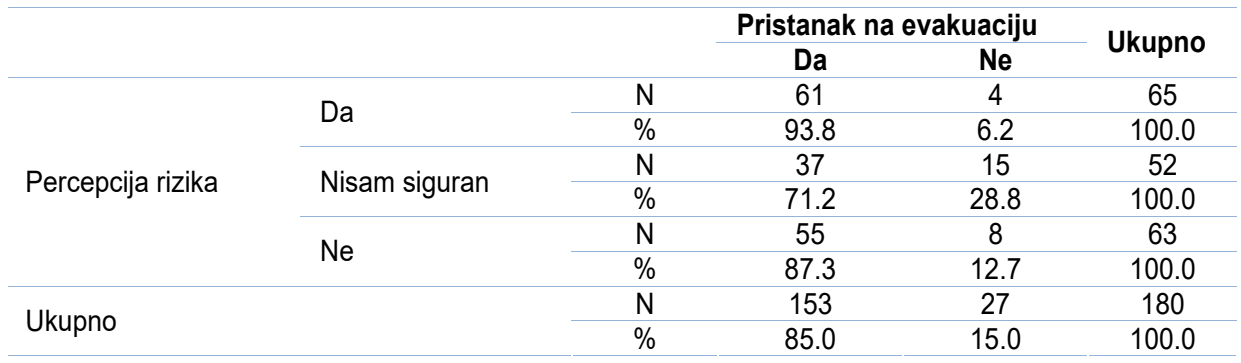

Kada je reč o ispitivanju statističke povezanosti, utvrđeno je da postoji povezanost između percepcije rizika i sprovođenja evakuacije $(p=.002)$. Dobijeni rezultati pokazuju da ispitanici koji percipiraju rizik u najvećoj meri bi pristali da se evakuišu. $U$ daljem radu, ispitan je uticaj prethodno iskustvo i straha na sprovođenje evakuacije ljudi. Rezultati unakrsnog tabeliranja pokazuju da od ukupnog broja ispitanika koji imaju prethodnog iskustva, $60 \%$ bi se evakuisalo dok $40 \%$ to ne bi učinilo. Sa druge strane, od ukupnog broja ispitanika koji nemaju prethodnog iskustva, $85.7 \%$ bi se evakuisalo dok $14.3 \%$ to ne bi učinilo. U odnosu na ispitanike koji nemaju prethodnog iskustva, $85.7 \%$ bi se evakuisalo dok, $13.3 \%$ to ne bi učinilo (tabela 7 ). 
Bezbednost

Tabela 7 - Rezultati unakrsnog tabeliranja prethodnog iskustva i sprovođenja evakuacije

\begin{tabular}{|c|c|c|c|c|c|}
\hline & \multicolumn{2}{|c|}{ Pristanak na evakuaciju } & \multirow{2}{*}{ Ukupno } \\
\hline & & & $\mathrm{Da}$ & $\mathrm{Ne}$ & \\
\hline \multirow{4}{*}{ Prethodno iskustvo } & \multirow{2}{*}{$\mathrm{Da}$} & $\mathrm{N}$ & 3 & 2 & 5 \\
\hline & & $\%$ & 60.0 & 40.0 & 100.0 \\
\hline & \multirow{2}{*}{$\mathrm{Ne}$} & $\mathrm{N}$ & 150 & 25 & 175 \\
\hline & & $\%$ & 85.7 & 14.3 & 100.0 \\
\hline \multicolumn{2}{|l|}{ Ukupno } & $\begin{array}{l}\mathrm{N} \\
\%\end{array}$ & $\begin{array}{c}153 \\
85.0\end{array}$ & $\begin{array}{c}27 \\
15.0\end{array}$ & $\begin{array}{c}180 \\
100.0\end{array}$ \\
\hline
\end{tabular}

Nadalje, ispitana je statistički značajna povezanost između prethodnog iskustva i sprovođenja evakuacije. Dobijeni rezultati pokazuju da ne postoji statistički značajna veza između donošenja odluka o sprovođenju evakuacije i prethodnog iskustva $(p=.112)$. Zatim, ispitana je povezanost straha od požara i sprovođenja evakuacije prilikom požara u stambenim objektima. Dobijeni rezultati pokazuju da od ukupnog broja ispitanika koji imaju strah od požara, $93.8 \%$ bi se evakuisalo dok $6.2 \%$ to ne bi učinilo. Pored toga, od ukupnog broja ispitanika koji nisu sigurni da li imaju strah od požara $71.2 \%$ bi se evakuisali dok $28.8 \%$ to ne bi učinilo. Na kraju, utvrđeno je da od ukupnog broja ispitanika koji nemaju stah od požara. $87.3 \%$ bi se evakuisalo, dok $12.7 \%$ to ne bi učinilo (tabela 8 ).

Tabela 8 - Rezultati unakrsnog tabeliranja straha i sprovođenja evakuacije

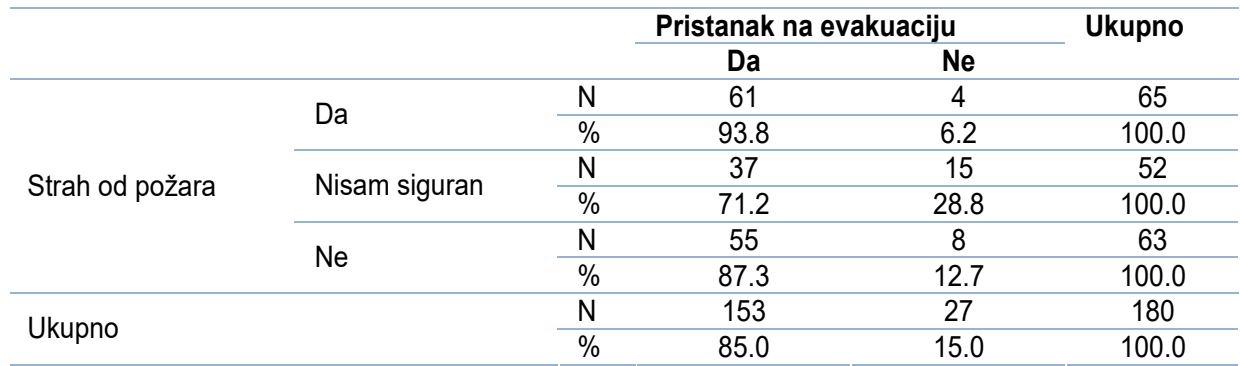

Zatim, ispitivana je povezanost između straha od požara i sprovođenja evakuacije. Dobijeni rezultati istraživanja pokazuju da postoji statistički značajna povezanost $(p=$ .002). Analizom dobijenih rezultata može se primetiti da bi ispitanici koji u najvećoj meri osećaju strah od požara pristali da se evakuišu.

\section{Diskusija}

Dobijeni rezultati istraživanja pokazuju da bi se najveći broj ljudi evakuisao u slučajevima izbijanja požara u stambenim objektima. Može se pretpostaviti da bi se većina ljudi evakuisala imajući u vidu nepredvidivu prirodu požara kao i druge različite produkte sagorevanja koji su nevidljivi, a mogu prouzrokovati ozbiljne posledice. Ipak, postavlja se pitanje razloga zbog kojih ljudi pristaju ili ne pristaju da se evakuišu u uslovima požara. U određenim 
situacijama, kada ljudi moraju da donesu samostalne odluke da li da se evakuišu ili ne, često se prave kobne greške koje se završavaju sa smrtnim posledicama. Naime, ukoliko je požara izbio na drugom spratu, on se ne može tako brzo proširiti imajući u vidu požarne segmente i postojeće sektore. Ipak, dim koji se brzo širi, često doprinosi širenju straha i ljudi iracionalno donose odluke da se započne evakuacija. U tim situacijama, usled dezorijentisanosti ljudi, oni često ostaju zarobljeni u stepenišnom prostoru. U takvim situacijama, oni su sprečeni da se vrate nazad do stana iz kojeg su izašli i tada često dolazi do njihovog gušenja i smrti. Polazeći od činjenice da ljudi takve odluke vrlo često donose usled nedovoljnog znanja iz oblasti bezbednosti, potrebno je doneti određene kampanje u okviru kojih će se građani na odgovarajući način edukovati o: uslovima neophodnim za nastanak i razvoj požara; karakteristikama požara u zatvorenom prostoru; načinima reagovanja u uslovima narušene bezbednosti; potencijalnim načinima zaštite u uslovima smanjenje vidljivosti.

Polazeći od činjenice da je čovek biološko i društveno biće, na njegove odluke da li će da se evakuiše ili neće deluje veliki broj faktora. Dobijeni rezultati istraživanja pokazuju da pol ispitanika ne utiče na donošenje odluke o sprovođenju evakuacije. To znači da ne postoji razlika između muškaraca i žene u pogledu njihove rešenosti da postupe po naredbu nadležnih organa tačnije vatrogasno-spasilačkih jedinica da se evakuišu u uslovima vanrednih situacija. Može se pretpostaviti biološke predispozicije nisu presudne u tom procesu odlučivanja o pristanku na evakuaciju. Dobijeni rezultati nisu u saglasnosti sa istraživanjem u kojem je utvrđeno da će se žene u odnosu na muškarce u većoj meri saglasiti sa evakuacijom u uslovima vanrednih situacija (Bateman \& Edwars, 2002). U literaturi se često nailazi na objašnjenje po kojem žene u većoj meri pristaju da se evakuišu iz razloga različitih perspektiva u nezi, pristupima podsticaja za evakuaciju, izloženostima riziku itd. $U$ odnosu na godine starosti ispitanika, dobijeni rezultati istraživanja nisu pokazali sličnosti sa polom. Naime, utvrđeno je da je donošenje odluke o sprovođenju evakuacije u vezi sa godinama starosti ispitanika. Utvrđeno je da najstariji ispitanici u najvećoj meri pristaju da se evakuišu u odnosu na mlađe koji to nerado čine. Može se pretpostaviti da se to događa zato što stariji građani nemaju mnogo snage i drugih sposobnosti da se samostalno brzo evakuišu. Pored toga, oni su vrlo ranjiviji u odnosu na ostalu populaciju i teže se oporavljaju. Sa druge strane, mlađa populacija često živi u ubeđenju da su zbog svoje mladosti nepobedivi i nezaustavljivi. Dobijeni rezultati istraživanja potvrđuju nalaze prethodnih istraživanja (Lazo et al., 2015).

U daljim analizama utvrđeno je da ne postoji povezanost bračnog statusa i donošenja odluka o pristanku na evakuaciju. Ispitanici koji su u braku, a i oni koji nisu na slične načine donose odluke o pristanku na evakuaciju. Svakako, potrebno je detaljnije ispitati razlike u odnosu na različite kategorije bračnog statusa. Nadalje, ispitan je i uticaj nivoa obrazovanja na donošenje odluka o pristanku na evakuaciju. Dobijeni rezultati ukazuju da se ispitanici koji imaju visoko obrazovanje u najmanjoj meri opredeljuju da se evakuišu u uslovima vanrednih situacija izazvanih požarima u stambenim objektima. Može se pretpostaviti da raspolažu većim brojem informacija pa se stoga teže odlučuju da pristanu na sprovođenje evakuacije. Svakako, potrebno je sprovesti dodatna istraživanja kako bi se ispitale spomenute tvrdnje. $U$ odnosu na rezultate prethodnih istraživanja, može se reći da se oni slažu većim brojem sprovedenih istraživanja (Huang et al., 2016). Pored ispitivanja uticaja demografskih karakteristika građana na donošenje odluka o sprovođenju evakuacije pristupilo se ispitivanju i drugih socio-ekonomskih psiholoških faktora koji 
igraju posebnu ulogu u takvom procesu. Od mogućih faktora za ispitivanje, ispitan je uticaj visine prihoda, percepcije rizika, zaposlenosti i straha. U odnosu na visinu prihoda, utvrđeno je da postoji statistički značajna povezanost sa pristankom za sprovođenje evakuacije. Utvrđeno je da na evakuaciju najmanje pristaju ispitanici koji imaju prihode ispod 76.000 dinara. Postavlja se pitanje, koji sve faktori u odnosu na više prihode utiču na pojedinca da odbije da se evakuiše. Potrebno je ispitati da li se radi o strahovima za sopstvenu imovinu ili drugim razlozima. Dobijeni rezultati istraživanja potvrđuju nalaze ranijih istraživanja (Whitehead et al., 2000).

Percepcija rizika od požara igra značajnu ulogu u procesu pripremanja i reagovanja u vanrednim situacijama. Ukoliko ljudi ne percipiraju određene rizike, oni neće hteti da preduzimaju određene mere, kao i da se evakuišu. Iz tih razloga, vrlo je značajno detaljno sagledati dobijene rezultate i na pravi način ih protumačiti. U odnosu na dobijene rezultate istraživanja, utvrđeno je da postoji statistički značajan uticaj na donošenje odluka o sprovođenju evakuacije. Pored toga, utvrđeno je da ispitanici koji na pravi način percipiraju rizike u najvećoj meri pristaju da se evakuišu. Na osnovu toga, može se konstatovati da postoji tesna veza između dobijenih rezultata i nivoa percepcije rizika. Analizom rezultata prethodnih istraživanja se može zaključiti da dobijeni rezultati odgovaraju utvrđenim rezultatima drugih istraživanja (Riad et al., 1999). Kada je reč o prethodnom iskustvu i strahu, utvrđeno je da samo strah ima značajnog uticaja na donošenje odluka o sprovođenju evakuacije. Naime, utvrđeno je da ispitanici koji u najvećoj meri osećaju strah, pristaju da se evakuišu. U odnosu na zdravorazumsko razmišljanje, očekivano je da će ispitanici koji u većoj meri osećaju strah pristati da se evakuišu polazeći od posledica sa kojima se mogu susresti ukoliko to ne učine. Tako dobijeni rezultati istraživanja su u saglasnosti sa rezultatima prethodnih istraživanja (Brumfiel, 2013).

\section{Zaključak}

Evakuacija ljudi iz stambenih objekata u uslovima vanrednih situacija predstavlja jedan od vrlo kompleksnih zadataka za pripadnike interventno-spasilačkih službi. Kompleksnost postupanja često proizilazi iz činjenice da ljudi ponekad iz neznanja, straha ili drugih faktora odbijaju da se evakuišu što prouzrokuje ozbiljne probleme. U takvim situacijama, saradnja spasilaca i evakuisanih ljudi je od presudnog značaja kako bi se smanjile posledice po ljude i njihovu imovinu. Sprovedeno istraživanje u kojem je ispitan nivo spremnosti ljudi da se evakuišu je od velikog značaja polazeći od činjenice da se rezultati takvog istraživanja mogu iskoristiti u kreiranju obrazovnih strategija i kampanja sa ciljem podizanja nivoa svesti građana i njihovih sposobnosti da se brzo i efikasno evakuišu.

Dobijeni rezultati su ukazali da bi se veliki broj ljudi evakuisao i da među njima postoje određene razlike u pogledu stavova o prihvatanju evakuacije. $U$ odnosu na građane koji bi odbili da se evakuišu, potrebno je sprovesti naknadna istraživanja kako bi se utvrdilo zašto oni odbijaju da se evakuišu i kojim se razlozima najviše rukovode. Svakako, ograničenje istraživanja se ogleda u tome da su ispitanici bili samo iz jedne lokalne samouprave i da je potrebno anketirati mnogo veći broj ljudi. Polazeći od prve postavljene hipoteze koja se odnosila na proveravanje tvrdnje da bi građani u većoj meri pristali da se evakuišu prilikom nastanka požara u odnosu na one koji na to ne bi pristali već bi sa- 
mostalno preduzimali određene preventivne mere da se požar na proširi može se istaći da je ona potvrđena što je konstatovano rezultatima istraživanja u radu. U odnosu na drugu postavljenu hipotezu u kojoj se polazi od proveravanja tvrdnje da bi muškarci u odnosu na žene, stariji građani u odnosu na mlađe, oni koji su u bračnom stanju u odnosu na one koji nisu u vezi i oni sa većim prihodima u većoj meri pristali da se evakuišu u vanrednim situacijama izazvanim požarima delimično potvrđena. Naime, rezultati su pokazali da u odnosu na pol ispitanika nije bilo statistički značajne razlike, ali i kod bračno statusa. Sa druge strane, u odnosu na godine starosti ispitanika i njihove prihode utvrđena je statistički značajna povezanost. Potrebno je nastaviti sa sprovođenjem istraživanja kako bi se u potpunosti sagledali svi faktori uticaja na proces donošenja odluke o sprovođenju evakuacije. Na kraju, u trećoj posebnoj hipotezi koja se odnosila na proveravanje tvrdnje da prethodno iskustvo, percepcija rizika, strahovi i visina prihoda utiču na donošenje odluke o pristanku na sprovođenje evakuacije u vanrednim situacijama izazvanim požarima, utvrđeno je da samo prethodno iskustvo ne utiče na donošenje odluke o sprovođenju evakuacije. Polazeći od sprovedenog istraživanja, potrebno je nastaviti sa sprovođenjem daljih istraživanja kako bi se u potpunosti sagledala priroda načina donošenja odluka o sprovođenju evakuacije ljudi u vanrednim situacijama izazvanim požarima.

\section{Literatura}

[1] Ajzen, I. (1991). The theory of planned behavior. Organizational behavior and human decision processes, 50(2), 179-211.

[2] Ajzen, I. (1991). The theory of planned behaviour. Organisational Behaviour and Human Decision Processes, 50, 179-211.

[3] Ajzen, I. (1998). Models of human social behaviour and their application to health psychology. Psychology and Health, 13.

[4] Ajzen, I. (2002). Perceived behavioral control, self-efficacy, locus of control, and the theory of planned behavior. Journal of Applied Social Psychology, 32(4), 665-683.

[5] Ajzen, I. (2011). Theory of planned behavior. Handb Theor Soc Psychol Vol One, 1(2011), 438.

[6] Aleksandrina, M., Budiarti, D., Yu, Z., Pasha, F., \& Shaw, R. (2019). Governmental Incentivization for SMEs' Engagement in Disaster Resilience in Southeast Asia. International Journal of Disaster Risk Management, 1(1), 32-50.

[7] Armitage, C. J., \& Conner, M. (2001). Efficacy of the theory of planned behaviour: A meta-analytic review. British Journal of Social Psychology, 40(4), 471-499.

[8] Bateman, J. M., \& Edwards, B. (2002). Gender and evacuation: A closer look at why women are more likely to evacuate for hurricanes. Natural Hazards Review, 3(3), 107-117.

[9] Bihari, M., \& Ryan, R. (2012). Influence of social capital on community preparedness for wildfires. Landscape and Urban Planning, 106(3), 253-261.

[10] Braun, A., Musse, S. R., de Oliveira, L. P. L., \& Bodmann, B. E. (2003). Modeling individual behaviors in crowd simulation. Paper presented at the Computer Animation and Social Agents, 2003. 16th International Conference.

[11] Braun, A., Musse, S. R., de Oliveira, L. P. L., \& Bodmann, B. E. (2003). Modeling individual behaviors in crowd simulation. Paper presented at the Computer Animation and Social Agents, 2003. 16th International Conference on.

[12] Bryan, J. (1983). An Investigation and Analysis of the Dynamics of the Human Behaviour in the M Brumfiel, G. (2013). Fukushima: Fallout of fear. Nature News, 493(7432), 290. 
[13] Carpenter, R. C. (2003). 'Women and children first': Gender, norms, and humanitarian evacuation in the Balkans 1991-95. International Organization, 57(4), 661-694.

[14] Chien, S.-W., \& Wu, G.-Y. (2008). The strategies of fire prevention on residential fire in Taipei. Fire Safety Journal, 43(1), 71-76.

[15] Conner, M., \& Armitage, C. J. (1998). Extending the theory of planned behavior: A review and avenues for further research. Journal of Applied Social Psychology, 28(15), 1429-1464.

[16] Cvetkovic, V. M. (2019). Risk Perception of Building Fires in Belgrade. International Journal of Disaster Risk Management, 1(1), 81-91.

[17] Cvetković, V. (2015). Spremnost za reagovanje na prirodnu katastrofu-pregled literature. Bezbjednost, policija i građani, 11(1-2), 165-183.

[18] Cvetković, V. M., Öcal, A., \& Ivanov, A. (2019). Young adults' fear of disasters: A case study of residents from Turkey, Serbia and Macedonia. International Journal of Disaster Risk Reduction, 101095. doi: https://doi.org/10.1016/j.ijdrr.2019.101095

[19] Cvetković, V., \& Gačić, J. (2017). Požari kao ugrožavajuća pojava sigurnosti: čimbenici utjecaja na znanje o požarima.

[20] Cvetković, V., Filipović, M., \& Gačić, J. (2018). Teorijski okvir istraživanja u oblasti katastrofa. Ecologica, 25(91), 545-551.

[21] Cvetković, V., Giulia, R., Ocal, A., Filipović, M., Janković, B., \& Eric, N. (2018). Childrens and youths' knowledge on forest fires: Discrepancies between basic perceptions and reality. Vojno delo, 70(1), 171-185.

[22] Cvetković, V., Noji, E., Filipović, M., Marija, M. P., Želimir, K., \& Nenad, R. (2018). Public Risk Perspectives Regarding the Threat of Terrorism in Belgrade: Implications for Risk Management Decision-Making for Individuals, Communities and Public Authorities. Journal of Criminal Investigation and Criminology/, 69(4), 279-298.

[23] Cvetković, V., Roder, G., Öcal, A., Tarolli, P., \& Dragićević, S. (2018). The Role of Gender in Preparedness and Response Behaviors towards Flood Risk in Serbia. International Journal of Environmental Research and Public Health, 15(12), 2761. doi: https://doi.org/10.3390/ijerph15122761

[24] Цветковић, В., \& Гачић, Ј. (2016). Евакуација у природним катастрофама. Београд: Задужбина Андрејевић.

[25] Цветковић, В., \& Филиповић, М. (2018). Испитивање перцепције ризика о пожарима у стамбеним објектима: демографски и социо-економски фактори утицаја. Војно дело, 70(5), 82-98.

[26] Fahy, R. F. (1995). Study of occupant behavior during the World Trade Center evacuation: Preliminary report of results.

[27] Fahy, R. F., \& Proulx, G. (2001). Toward creating a database on delay times to start evacuation and walking speeds for use in evacuation modeling. Paper presented at the 2 nd international symposium on human behaviour in fire.

[28] Filippoupolitis, A., \& Gelenbe, E. (2009). A distributed decision support system for building evacuation. Paper presented at the Human System Interactions, 2009. HSI'09. 2nd Conference on.

[29] Filippoupolitis, A., \& Gelenbe, E. (2009). A distributed decision support system for building evacuation. Paper presented at the Human System Interactions, 2009. HSI'09. 2nd Conference.

[30] Gershon, R. (2006). The world trade center evacuation study: Lessons for other high rise office buildings. Paper presented at the NFPA World Safety Conference \& Exposition.

[31] Gwynne, S., Galea, E. R., Owen, M., Lawrence, P. J., \& Filippidis, L. (1999b). A review of the methodologies used in evacuation modelling. Fire and materials, 23(6), 383-388.

[32] Gwynne, S., Galea, E. R., Owen, M., Lawrence, P. J., \& Filippidis, L. (1999a). A review of the methodologies used in the computer simulation of evacuation from the built environment. Building and Environment, 34(6), 741-749. 
[33] Hall, J. R. (2000). High-rise building fires: The Association.

[34] Hall, J. R. (2004). How many people can be saved from home fires if given more time to escape? Fire technology, 40(2), 117-126.

[35] Hareesh, P. (2000). Evacuation Simulation: Visualization Using Virtual Humans in a Distributed Multi-User Immersive VR System. Proc. VSMM2000.

[36] Heath, Y., \& Gifford, R. (2002). Extending the theory of planned behavior: Predicting the use of public transportation. Journal of Applied Social Psychology, 32(10), 2154-2189.

[37] Holborn, P., Nolan, P., \& Golt, J. (2003). An analysis of fatal unintentional dwelling fires investigated by London Fire Brigade between 1996 and 2000. Fire Safety Journal, 38(1), 1-42.

[38] Holborn, P., Nolan, P., \& Golt, J. (2003). An analysis of fatal unintentional dwelling fires investigated by London Fire Brigade between 1996 and 2000. Fire Safety Journal, 38(1), 1-42.

[39] Huang, S. K., Lindell, M. K., \& Prater, C. S. (2016). Who leaves and who stays? A review and statistical meta-analysis of hurricane evacuation studies. Environment and Behavior, 48(8), 991-1029.

[40] Joo, J., Kim, N., Wysk, R. A., Rothrock, L., Son, Y.-J., Oh, Y.-g., \& Lee, S. (2013). Agentbased simulation of affordance-based human behaviors in emergency evacuation. Simulation Modelling Practice and Theory, 32, 99-115.

[41] Kihila, J. M. (2017). Fire disaster preparedness and situational analysis in higher learning institutions of Tanzania. Jàmbá: Journal of Disaster Risk Studies, 9(1), 1-9.

[42] Kumiko, F., \& Shaw, R. (2019). Preparing International Joint Project: Use of Japanese Flood Hazard Map in Bangladesh. International Journal of Disaster Risk Management, 1(1), 62-80.

[43] Laban, M. Đ., Popov, S. B., Vukoslavčević, S. R., \& Šupić, S. M. (2015). Evacuation routes performances and fire safety of buildings. Tehnika, 70(4), 599-606.

[44] Lazo, J. K., Bostrom, A., Morss, R. E., Demuth, J. L., \& Lazrus, H. (2015). Factors affecting hurricane evacuation intentions. Risk analysis, 35(10), 1837-1857.

[45] Li, H., Tang, W., \& Simpson, D. (2004). Behaviour based motion simulation for fire evacuation procedures. Paper presented at the Theory and Practice of Computer Graphics, 2004. Proceedings.

[46] Madden, T. J., Ellen, P. S., \& Ajzen, I. (1992). A comparison of the theory of planned behavior and the theory of reasoned action. Personality and Social Psychology Bulletin, 18(1), 3-9.

[47] McGee, T. K., McFarlane, B. L., \& Varghese, J. (2009). An examination of the influence of hazard experience on wildfire risk perceptions and adoption of mitigation measures. Society and Natural Resources, 22(4), 308-323.

[48] Moritz, M. A. (2003). Spatiotemporal analysis of controls on shrubland fire regimes: age dependency and fire hazard. Ecology, 84(2), 351-361.

[49] Nelson, K. C., Monroe, M. C., \& Johnson, J. F. (2005). The look of the land: homeowner landscape management and wildfire preparedness in Minnesota and Florida. Society and Natural Resources, 18(4), 321-336.

[50] Ocal, A. (2019). Natural Disasters in Turkey: Social and Economic Perspective. International Journal of Disaster Risk Management, 1(1), 51-61.

[51] Pan, X., Han, C. S., Dauber, K., \& Law, K. H. (2007). A multi-agent based framework for the simulation of human and social behaviors during emergency evacuations. Al \& SOCIETY, 22(2), 113-132.

[52] Paton, D., \& Tedim, F. (2012). Wildfire and community: facilitating preparedness and resilience: Charles $C$ Thomas Publisher.

[53] Proulx, G. (1995). Evacuation time and movement in apartment buildings. Fire Safety Journal, 24(3), 229-246.

[54] Proulx, G., Latour, J. C., \& MacLaurin, J. W. (1994). Housing evacuation of mixed abilities occupants: National Research Council Canada, Institute for Research in Construction, National Fire Laboratory. 
[55] Ramachandran, G. (1990). Human behavior in fires-a review of research in the United Kingdom. Fire technology, 26(2), 149-155.

[56] Riad, J. K., Norris, F. H., \& Ruback, R. B. (1999). Predicting evacuation in two major disasters: Risk perception, social influence, and access to resources 1. Journal of Applied Social Psychology, 29(5), 918-934.

[57] Runyan, C. W., Bangdiwala, S. I., Linzer, M. A., Sacks, J. J., \& Butts, J. (1992). Risk factors for fatal residential fires. New England journal of medicine, 327(12), 859-863.

[58] Shi, J., Ren, A., \& Chen, C. (2009). Agent-based evacuation model of large public buildings under fire conditions. Automation in Construction, 18(3), 338-347.

[59] Shields, T., \& Boyce, K. (2000). A study of evacuation from large retail stores. Fire Safety Journal, 35(1), 25-49.

[60] Sime, J. D. (1984). Escape behaviour in fires: Panic or affiliation. ProQuest Dissertations \& Theses.

[61] Sparks, P., Shepherd, R., \& Frewer, L. J. (1995). Assessing and structuring attitudes toward the use of gene technology in food production: The role of perceived ethical obligation. Basic and Applied Social Psychology, 16(3), 267-285.

[62] Walker, B., Associates, I., \& Bryan, J. (1993). Human Behavior in Fires: Bonnie Walker \& Associates Rehoboth Beach.

[63] Wang, P., Luh, P. B., Chang, S. C., \& Sun, J. (2008). Modeling and optimization of crowd guidance for building emergency evacuation. In Automation Science and Engineering, IEEE International Conference (pp. 328-334).

[64] Whitehead, J. C., Edwards, B., Van Willigen, M., Maiolo, J. R., Wilson, K., \& Smith, K. T. (2000). Heading for higher ground: factors affecting real and hypothetical hurricane evacuation behavior. Global Environmental Change Part B: Environmental Hazards, 2(4), 133-142.

[65] Xuesong, G., \& Kapucu, N. (2019). Examining Stakeholder Participation in Social Stability Risk Assessment for Mega Projects using Network Analysis. International Journal of Disaster Risk Management, 1(1), 1-31.

[66] Zeng, Y., Murphy, S. Ó., Sitanayah, L., Tabirca, T., Truong, T., Brown, K., \& Sreenan, C. (2009). Building fire emergency detection and response using wireless sensor networks.

[67] Žarković Palijan, T., Kovačević, D., Kovač, M., \& Sarilar, M. (2014). Profili osoba koje podmeću požare. Policija i sigurnost, 22(3/2013), 317-327.

[68] Јаковљевић, В. (2011). Цивилна заштита у Републици Србији. Београд: Факултет безбедности, 2011.

[69] Нововић, М. (2019). Евакуација из стамбених објеката у ванредним ситуацијама изазваним пожарима (мастер рад). Београд: Факултет безбедности. 